\title{
KARAKTER MORFOLOGI BERAS SEBAGAI PEMBEDA VARIETAS PADI
}

\author{
Dicky Frengky Hanas, Eniek Kriswiyanti dan I Ketut Junitha \\ Program Studi Magister Ilmu Biologi, Fakultas Matematika dan Ilmu Pengetahuan Alam, Universitas \\ Udayana, Denpasar-Bali \\ Email: dickyfrengkyhanas@yahoo.co.id
}

\begin{abstract}
This study aims to determine the morphological character of white, red and black rice as a differentiator of rice varieties. This research uses 10 rice samples which are 6 local rice of Kupang, 2 varieties of local superior rice and 2 Italian rice. The method used is direct observation of both qualitative and quantitative characteristics of rice. Long grain size of rice is a character that can indicate the distinguishing of local rice, domestic superior and rice from abroad. Character of rice morphology is a character very easily observed in knowing the difference of rice varieties. Character of rice morphology are easily characters observed in knowing the difference of rice varieties. Characters difference can be used to determine the adulteration of rice mixed.
\end{abstract}

Key words: Character, Morphology, Rice mixed.

\section{PENDAHULUAN}

Padi termasuk kelompok tumbuhan berbiji (serealia) penghasil beras dengan kandungan karbohidrat yang tinggi dan menjadi sumber pangan utama masyarakat Asia. Sebagai sumber pangan masyarakat yang esensial ketersediaan beras harus dapat mengimbangi kebutuhan masyarakat, oleh sebab itu pemerintah terus berupaya berupaya melakukan peningkatan bidang pertanian seperti pemilihan bibit unggul maupun penggunaan teknologi pangan untuk menunjang peningkatan produksi beras.

Produksi beras dalam negeri diharapkan dapat memenuhi kebutuhan pangan masyarakat. Akan tetapi pada kenyataannya jika hanya mengandalkan produksi beras dalam negeri baik itu beras padi lokal maupun unggul, belum mampu mengimbangi kebutuhan beras masyarakat sehingga untuk memenuhi kebutuhan akan beras dalam negeri pemerintah juga melakukan import beras dari negara tetangga (Christianto, 2013; Sari, 2014).

Kebutuhan yang cukup tinggi ini menjadikan beras sebagai komoditas yang menarik bagi pelaku bisnis dan potensial untuk dimanupulasi yang menimbulkan peluang adanya tindak pidana. Proses pendistribusian beras melewati beberapa tahapan dari produsen, pedagang pengepul, grosir, pedagang eceran sebelum sampai pada konsumen. Dalam tahapannya, pelaku distribusi sering ditemukan melakukan pencampuran beras (pengoplosan), beda kualitas ataupun antar beras yang berbeda tujuan peruntukannya, misalnya beras bersubsidi dengan beras non subsidi (Kompas.com, 10 Oktober 2016).

Karakter beras yang secara sepintas sulit dibedakan antar varietasnya serta kurangnya pengetahuan mengenai karakter spesifik beras tiap varietas, menjadikan masyarakat pembeli sebagai konsumen sering tidak peduli atau kurang teliti terhadap bentuk maupun ukuran beras yang dibeli sehingga tidak dapat membedakan antara beras yang dicampur dan beras yang tidak dicampur. Banyaknya varietas padi dengan kemiripan karakter, memperbesar peluang pencapuran (pengoplosan) beras dalam pendistribusian.

Pengoplosan beras merupakan tindakan pencampuran dua atau lebih varietas beras dengan komposisi tertentu. Kegiatan pengolosan biasanya dilakukan untuk mendapatkan kualitas dan harga yang tepat serta memakai merek atau brand tertentu untuk mempermudah pemasarannya dengan tujuan mendapatkan keuntungan yang besar namun merugikan konsumen sehingga kegiatan pengoplosan dapat dikategorikan sebagai penipuan yang bertentangan dengan undang-undang perlindungan konsumen (Ramelan, 2008).

Plasma nutfah padi sangat beranekaragam baik itu padi hibrida, unggul dan lokal. Hasil eksplorasi terhadap plasma nutfah padi lokal Indonesia dari tahun 1995 sampai 2002, ditemukan sekitar 1127 varietas (Silitonga, 2004). Di antara sekian ribu varietas, padi yang satu sama lain mempunyai ciri khas tersendiri sehingga dari segi bentuk (morfologi) tidak ada varietas padi yang mempunyai bentuk yang sama. Perbedaan yang tampak antar varietas padi disebabkan oleh perbedaan sifat varietas. Namun demikian, di antara ribuan varietas juga terdapat beberapa sifat atau karakter yang sama ataupun mirip (Silitonga, 2004). Oleh karena itu diperlukan karakterisasi beras yang dapat digunakan untuk kepentingan forensik terkait pengoplosan beras. 


\section{METODOLOGI PENELITIAN}

Sampel beras yang digunakan dalam pengamatan yaitu 6 varietas beras padi gogo lokal dari Kabupaten Kupang: Aen Molo, Aen Muti, Aen Me'e putih (beras putih); Aen Lekes, Aen Me'e merah (beras merah); Aen Metan (beras hitam); 2 varietas beras padi unggul (beras merah dan beras putih ciherang) dan 2 varietas beras itali (beras merah dan beras hitam). Beras yang digunakan merupakan beras pecah kulit. Pengamatan dilaboratorium dilakukan dari bulan Maret sampai Mei 2017 di Laboratorium Serulogi dan Biologi Molekuler UPT Forensik Universitas Udayana Bukit Jimbaran. Alat yang digunakan antara lain: timbangan analitik KERN, jangka sorong, micrometer skrup dan penggaris.

\section{HASIL DAN PEMBAHASAN}

Warna beras yang digunakan terdiri dari beras putih, beras merah dan beras hitam. Namun semua beras yang digunakan memiliki bagian tengah beras (endosperm) berwarna putih. Warna beras berbeda dikarenakan memiliki perbedaan warna kulit ari (aleuron) yang disebabkan oleh perbedaan kandungan pigmen antosianin pada lapisan aleuron. Beras merah dan beras hitam memiliki kandungan antosianin yang sangat tinggi sehingga menjadikan beras warna merah menjadi merah kecoklatan atau ungu kehitaman (Takashi et al., 2001; El-Sayed et al., 2006).

Tabel warna, Bentuk dan Ukuran Beras

\begin{tabular}{ccccccc}
\hline Varietas Padi & \multicolumn{5}{c}{ Karakter } \\
\cline { 2 - 6 } & Warna beras & Berat $(\mathbf{g})$ & $\begin{array}{c}\text { Panjang } \\
(\mathbf{m m})\end{array}$ & $\begin{array}{c}\text { Lebar } \\
(\mathbf{m m})\end{array}$ & $\begin{array}{c}\text { Tebal } \\
(\mathbf{m m})\end{array}$ & Bentuk \\
\hline Aen Molo & Putih & 0,024 & 5,71 & 2,84 & 2,01 & Membulat \\
\hline Aen Muti & Putih & 0,021 & 6,31 & 2,12 & 1,77 & Ramping \\
\hline Aen Me'e putih & Putih & 0,021 & 5,87 & 2,50 & 1,73 & Sedang \\
\hline Ciherang & Putih & 0,021 & 6,89 & 1,94 & 1,75 & Ramping \\
\hline Aen Lekes & Merah & 0,020 & 5,52 & 2,48 & 1,85 & Sedang \\
\hline Aen Me'e merah & Merah & 0,021 & 5,96 & 2,51 & 1,77 & Sedang \\
\hline Beras Merah Unggul & Merah & 0,022 & 7,21 & 1,88 & 1,76 & Ramping \\
\hline Beras Merah Italia & Merah & 0,026 & 8,23 & 1,91 & 1,88 & Ramping \\
\hline Aen Metan & Hitam & 0,023 & 5,91 & 2,62 & 1,82 & Sedang \\
\hline Beras Hitam Italia & Hitam & 0,025 & 6,52 & 2,55 & 1,74 & Sedang \\
\hline
\end{tabular}

Kelompok beras merah (Aen Lekes, Aen Me'e merah, beras merah unggul dan beras Italia) memiliki warna beras yang sangat mirip yaitu merah kecoklatan. Beras hitam Italia memiliki warna yang lebih gelap dan merata pada seluruh permukaan beras sedangkan beras hitam lokal (Aen Metan) memiliki warna permukaan butir beras yang bervariasi dengan sedikit warna kecoklatan. Macam warna beras padi beras hitam terdiri dari warna beras ungu maupun ungu bervariasi (Sa'adah dkk, 2013). Kelompok beras putih (Aen Molo, Aen Muti, Aen Me'e putih dan Ciherang) memiliki warna yang mirip dan tidak mudah dibedakan bila dilihat sepintas. Beras Aen Molo dan Aen Me'e memiliki warna beras yang agak buram bila dibandingkan beras Aen Muti dan Ciherang.
Beras putih dalam penelitian ini memiliki bobot rata-rata antara 0,021-0,024 g. Beras putih lokal Kupang (Aen Molo) memiliki bobot 0,024 g, sedangkan dua beras lokal kupang lainnya serta beras putih unggul Ciherang memiliki bobot yang sama yaitu $0,021 \mathrm{~g}$. Beras merah Italia memiliki bobot $(0,026 \mathrm{~g})$ yang jauh lebih besar dari beras merah lokal Kupang maupun beras merah unggul $(0,021$ $0,022 \mathrm{~g})$. Bobot beras hitam Italia $(0,025 \mathrm{~g})$ juga memiliki bobot yang lebih besar dari beras hitam lokal Kupang (0,023 g).

$$
\text { Depatermen }
$$

Pertanian

(2003), mengklasifikasikan beras berdasarkan ukuran panjang beras menjadi beberapa kelompok yaitu: Pendek ( $<5,51 \mathrm{~mm})$ Sedang (5,51-6,60 mm), Panjang $(6,61-7,50 \mathrm{~mm})$ dan Sangat panjang $(>7,50 \mathrm{~mm})$. Untuk beras putih, hasil pengukuran rata-rata panjang 
beras pecah kulit terhadap beras padi gogo lokal Kabupaten Kupang dikategorikan berukuran sedang (5,71-6,31 mm) sedangkan beras putih unggul ciherang dikategorikan berukuran panjang (6,89 $\mathrm{mm})$. Untuk beras berwarna merah, beras padi gogo lokal Kabupaten Kupang dikategorikan berukuran sedang $(5,52-5,96 \mathrm{~mm})$; beras merah unggul termasuk beras berukuran panjang $(7,21 \mathrm{~mm})$ sedangkan beras merah italia termasuk beras berukuransangat panjang $(8,23 \quad \mathrm{~mm})$.

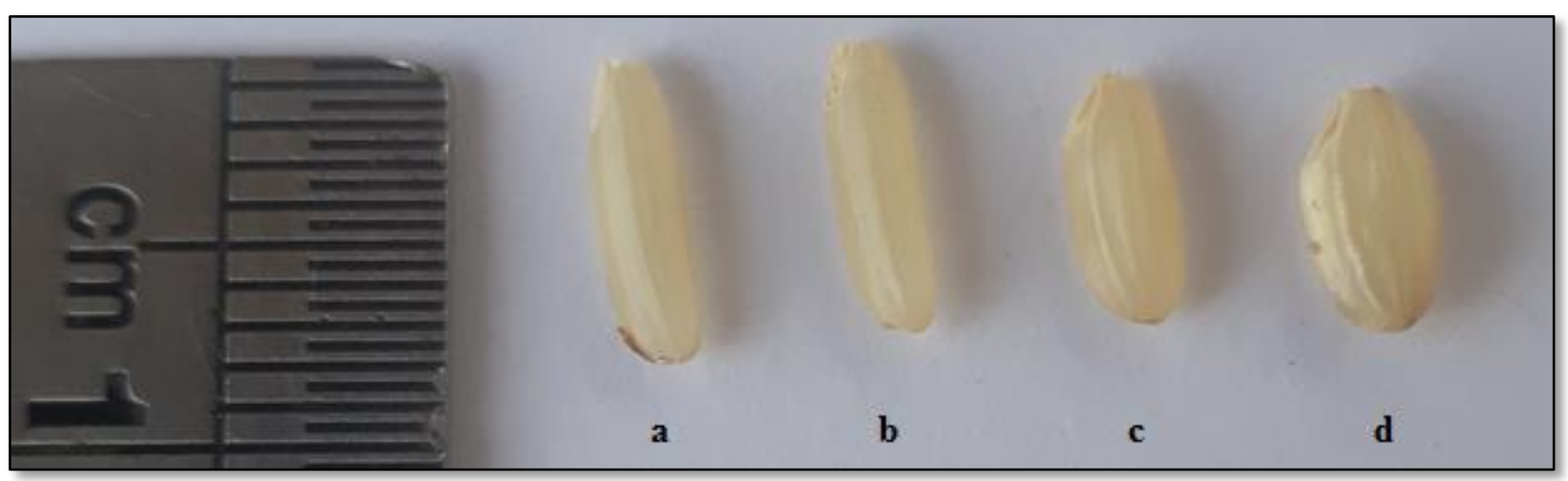

Gambar 1. Beras Putih

Keterangan : a. Ciherang, b. Aen Muti, Aen Me'e putih, d. Aen Molo

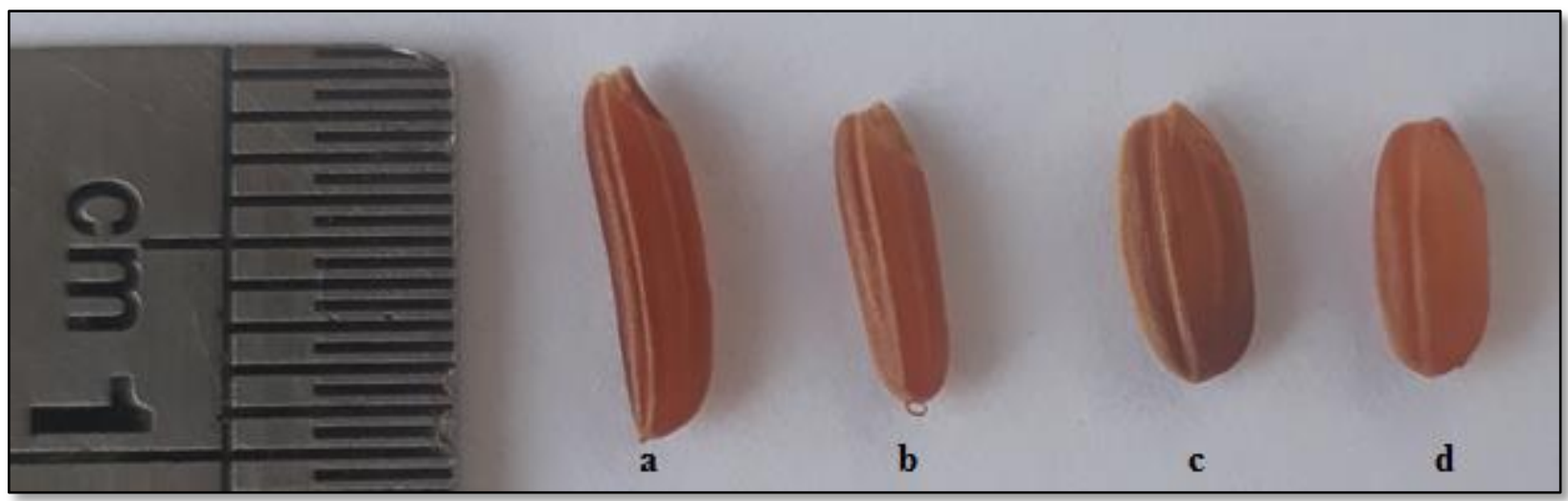

Gambar 2. Beras Merah

Keterangan: a. Merah Italia, b. Merah Unggul, c. Aen Me'e Merah, d. Aen Lekes

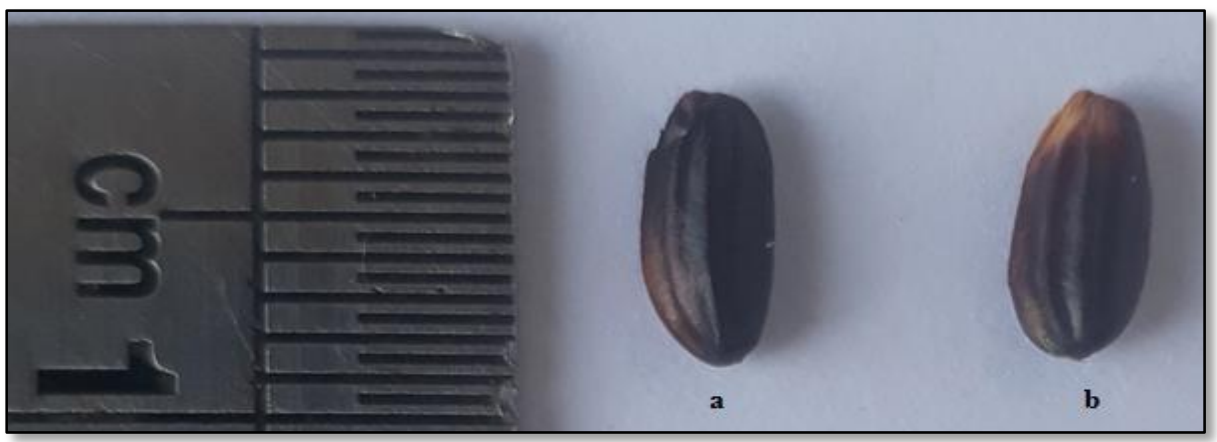

Gambar 3. Beras Hitam

Keterangan: a. Hitam Italia, b. Aen Metan

Ukuran rata-rata lebar beras putih lokal Kupang antara 2,12-2,84 mm sedangkan beras putih unggul Ciherang 1,94 mm. Untuk beras berwarna merah, beras lokal Kupang memiliki lebar antara 
2,84-2,51 mm; beras merah unggul 1,88 $\mathrm{mm}$ sedangkan beras merah italia $1,91 \mathrm{~mm}$. Untuk beras berwarna hitam, beras lokal Kupang memiliki ukuran lebar 2,62 mm sedangkan beras hitam Italia memiliki lebar 2,55 mm. Hasil pengukuran lebar beras memunjukkan bahwa beras lokal Kupang memiliki ukuran lebar yang lebih besar dibandingkan beras unggul Indonesia maupun beras Italia baik untuk beras berwarna putih, merah maupun beras hitam.

Ketebalan beras pecah kulit untuk beras putih lokal Kupang antara 1,73-2,01 mm, sedangkan beras putih unggul Ciherang memiliki tebal beras 1,75 mm. Untuk beras merah, beras lokal Kupang memiliki ketebalan antara 1,77-1,85 mm; beras merah unggul 1,76 mm sedangkan merah Italia $1,88 \mathrm{~mm}$. Untuk beras hitam, beras lokal Kupang memiliki ketebalan 1,82 $\mathrm{mm}$ sedangkan beras hitam Italia memiliki ketebalan 1,74 mm. Beras putih lokal Kupang dan beras putih Unggul Ciherang memiliki ketebalan yang tidak jauh berbeda begitu pula untuk beras merah, namun beras merah Italia memiliki ketebalan yang lebih dibandingkan beras merah lokal Kupang maupun beras merah unggul. Untuk ukuran ketebalan beras hitam, beras lokal Kupang memiliki ketebalan yang lebih dibandingkan beras hitam Italia.

Bentuk beras pecah kulit dapat ditentukan berdasarkan rasio antara ukuran panjang dan lebar beras yaitu: membulat/bold $(<2,1)$, sedang/medium $(>2,1-3)$ dan ramping/slender (>3) (Irawan dan Purbayanti, 2007). Hasil pengukuran rasio panjang dan lebar beras pecah kulit, beras putih lokal Kupang memiliki bentuk membulat, sedang dan ramping sedangkan beras putih unggul Ciherang berbentuk ramping. Beras merah lokal Kupang memiliki bentuk sedang sedangkan beras merah unggul Ciherang dan beras merah Italia memiliki bentuk beras ramping. Beras hitam lokal Kupang dan beras hitam Italia memiliki bentuk beras yang mirip yaitu sedang.

Karakter morfologi beras (panjang, lebar dan tebal) merupakan karakter sangat mudah diamati dalam menentukkan perbedaan varietas beras. Ukuran panjang butir beras merupakan karakter pembeda yang dapat digunakan untuk mengamati perbedaan varietas beras selain bentuk, lebar dan tebal beras. Ukuran panjang beras putih lokal Kupang (5,71-6,31 mm) lebih pendek dibandikan panjang beras putih unggul $(6,89 \mathrm{~mm})$. Ukuran panjang beras merah lokal Kupang $(5,52-5,96 \mathrm{~mm})$ lebih pendek dari beras merah unggul $(7,21 \mathrm{~mm})$ dan ukuran ini lebih pendek bila dibandingkan dengan beras merah Italia. Ukuran panjang beras hitam lokal Kupang $(5,91 \mathrm{~mm})$ lebih pendek dibandingkan beras hitam Italia $(6,52 \mathrm{~mm})$. Perbedaan karakter ini dapat digunakan untuk mengetahui adanya tindakan pengoplosan beras yang akhir-akhir ini marak terjadi dengan mencapur beras lokal maupun beras unggul
Indonesia dengan beras yang diimport dari negara lain. Untuk memastikan pengoplosan beras belum ada standar parameter baku yang digunakan sebagai patokan untuk menentukan perbandingan presentase antar beras yang oplosan atau tidak. Penelitian tentang kontaminasi dua atau lebih jenis beras dalam proses penggilingan sangat diperlukan.

\section{KESIMPULAN}

Karakter morfologi beras berbeda-beda untuk tiap varietas padi baik itu beras putih, merah maupun hitam. Ukuran panjang butir beras merupakan karakter pembeda yang dapat digunakan untuk mengamati perbedaan varietas beras selain bentuk, lebar dan tebal beras. Perbedaan karakter ini dapat digunakan untuk mengetahui adanya indikasi tindakan pencampuran (pengoplosan) beras dalam kepentingan forensik.

\section{DAFTAR PUSTAKA}

Christianto, Edward. 2013. Faktor yang Mempengaruhi Volume Impor Beras Di Indonesia. Jurnal JIBEKA; 7(2): 38 - 43.

Departemen Pertanian, Badan Penelitian dan Pengembangan Pertanian, Komisi Nasional Plasma Nutfah. 2003. Panduan Sistem Karakterisasi dan Evaluasi Tanaman Padi. Bogor: Sekretariat Komisi Nasional Plasma Nutfah.

El-Sayed M. Abdel-Aal, J. Christopher Young, and Iwona Rabalski. 2006. Anthocyanin Composition in Black, Blue, Pink, Purple, and Red Cereal Grains .J. Agricultural Food and Chemical; 54 (13): 4696-4704.

Irawan, B dan K. Purbayanti. 2008. Karakterisasi dan Kekerabatan Kultivar Padi Lokal Di Desa Rancakalong, Kecamatan Rancakalong, Kabupaten Sumedang. Makalah Jurusan Biologi Fakultas Matematika dan Ilmu Pengetahuan Alam Universitas Padjajaran. Bandung.

Kompas.com, 10 Oktober 2016. Polisi Tetapkan Satu Tersangka dalam Kasus Beras Oplosan. Kompas.com (serial online), [diakses 7 Nopember 2016]: http://nasional.kompas.com/read/2016/10/10/2 1171041/polisi.tetapkan.satu.tersangka.dalam. kasus.beras.oplosan.

Rahardi Ramelan. 2008. Oplos atau Blending,[diakses 11 Nopember 2016]: ramelan.com/wp/articles/2008/01/30/oplosatau-blending/

Sa'adah, I.R., Supriyanta dan Subejo. 2013. Keragaman Warna Gabah dan Warna Beras Varietas Lokal Padi Beras Hitam (Oryza Sativa L.) Yang Dibudidayakan Oleh Petani 
Kabupaten Sleman, Bantul, dan Magelang. Vegetalika; 2(3): 13-20.

Sari, Ratih Kumala 2014. Analisis Impor Beras Di Indonesia. Economics Development Analysis Journal; 3(2): 320-326.

Silitonga, T.S. 2004. Pengelolaan dan Pemanfaatan Plasma Nutfah Padi di Indonesia. Buletin Plasma Nutfah; 10(2): 56-71.

Takashi I, Bing X, Yoichi Y, Masaharu N, Tetsuya K. 2001. Antioxidant Activity of Anthocyanin Extract from Purple Black Rice. Journal Medical Food; 4:211-218. 